\title{
Entrepreneurial Capability and New Product Development Performance in Micro and Small Enterprises: The Moderating Role of Financial Literacy
}

\author{
Perminas Pangeran
}

Business Faculty, Duta Wacana Christian University, Jl. Dr Wahidin Sudirohusodo, 5-25, Yogyakarta - Indonesia, 55224

Doi:10.5901/mjss.2016.v7n1p97

\begin{abstract}
The purpose of this study is to examine the moderating effect of financial literacy on entrepreneurial capabilities and new product development performance in micro- and small-sized enterprises (MSEs). The respondents in this study consisted of 133 owners of micro and small firms, located in Yogyakarta Indonesia. Moderated regression analysis is used for testing hypotheses. The results revealed that financial literacy moderated relationship between risk taking and new product development performance. Likewise, financial literacy moderated the relationship between proactiveness and new product development performance, while financial literacy showed no such effect on innovativeness and new product development performance. The results also showed that financial literacy had impact on new product development performance. Moreover, risk taking and proactiveness influenced on new product development performance.
\end{abstract}

Keywords: Entrepreneurial Capability, New Product Development Performance, Financial Literacy.

\section{Introduction}

Entrepreneurial capability has been recognized as a major determinant for firm's performance (Covin \& Slevin, 1999; Lumskin \& Dess, 1999; Su, Xie \& Li, 2011). However, the extant studies show inconsistent results on the effect of entrepreneurial capabilities on the firm's performance. On one hand, Davis et al. (2010) proves that high risk tolerance, innovativeness and proactiveness have effect on firm performance. They find that there is a positive relationship between entrepreneurial capability and firm's performance under dynamic environmental conditions. Moreover, studies show that the entrepreneurial orientation positively affects business performance (Frank, Kessler \& Fink, 2010; Su, Xie \& Li, 2011). On the other hand, the results show that the entrepreneurial orientation has no effect on the firm's performance (Matsuno, Mentzer, \& Ozsomer, 2002; Frishammar \& Horte, 2007). These inconsistencies can occur due to the impact of entrepreneurial capabilities on firm's performance may depend on the effect of contingency.

In this case, the moderating role of financial literacy becomes an important consideration. Studies on the financial literacy indicate that financial literacy among young entrepreneurs are above average and financial literacy contributes significantly towards entrepreneurial skills (Oseifuah, 2010). Additionally, Bosma and Harding (2006) reveal that poor financial literacy and inadequate management practices would restrict entrepreneurial activity, such as new product development performance. Nevertheless, existing research has not been paying attention to the role of financial literacy as a moderating variable in the relationship between entrepreneurial capabilities and new product development performance.

Financial literacy is an important issue for finance and society economic development. It seems there is a gap between the needs and the realities of individuals for financial literacy. For entrepreneurs of Micro-and Small-Sized Enterprises (MSEs), financial literacy is a requirement. They should be able to make an informed judgment and effective decisions about the use and management of funds. Financial literacy has major implications for the well-being and the ability of individual entrepreneurial activity (Bosma \& Harding, 2006; Taylor \& Wagland, 2011). People with high-financial literacy allow individual to make better financial decisions, such as budgets, expenditures, savings, investment, and financial risk management. Implications of high financial literacy that can increase the income and welfare of micro and small entrepreneurs. However, the reality of the financial literacy levels of society, especially the entrepreneur is still questionable. Nevertheless, the role of financial literacy unfortunately rarely gets the attention of research.

This study aims to examine the moderating role of financial literacy on the relationship between entrepreneurial capabilities and new product development performance of MSEs in terms of Indonesian perspective. This study specifically examines whether financial literacy serves as a moderating in the relationship between the three dimensions of entrepreneurial capabilities, namely risk taking, innovativeness and proactiveness on new product development 
performance in micro-and small-sized enterprises, located in Yogyakarta, Indonesia. Previous research ignored the moderarting role of financial literacy in each dimension of entrepreneurial capabilities. In this case the financial literacy may act as a moderating variable in the relationship between one of the dimensions of the entrepreneurial capability and new product development performance.

This research contributes to some things. Firstly, the research emphasize on three dimension of entrepreneurial capabilities, namely innovativeness, risk taking, and proactiveness, and their effect on new product development performance in micro- and small-sized enterprises. Existing studies relate to the role of financial literacy moderation is rarely done in the case of SMEs in Indonesia. Secondly, the study specifically focuses on financial literacy. In this regard, studies reveal whether financial literacy is as moderating variables. Such a study has not been done in the case of Indonesian perspective. The prior study indicated that the financial literacy level among entrepreneurs is above average and the financial literacy significantly affect their entrepreneurial skills (Oseifuah, 2010).

\section{Literature Review and Hypothesis Development}

\subsection{Entrepreneurial capabilities and New Product Development Performance}

Hunt (2000) and Frishammar and Horte (2007) state that an organization can not know what the product alternatives would customers prefer, therefore these companies face uncertainty. In this case the company needs to be innovative, proactive and risk takers. This means that organizations need to act with the entrepreneurial orientation. The first dimension of entrepreneurial orientation is innovativeness. Innovativeness refers to a willingness of firms to involve in and support new idea, creativity, novelty, experimentation that may lead to new products development (Lumpkin \& Dess, 1996, Mengue \& Auh, 2006). Innovativeness shows the company's desire to depart from existing technologies and practices. Frishammar and Horte (2007) show that innovativeness has a positive effect on the performance of the firm's new product development.

The second dimension of the entrepreneurial capability is risk taking. Risk taking refers to the willingness of managers or owners to make large and risky resources commitments to new product and to incur heavy debt in the persuit of opportunity (Lumpkin \& Dess, 1996). Although too much risks can jeopardize company's performance, however, risk is inevitable since the success of a new product development can not be known beforehand. Prototype may fail in manufacturing and new design may fail in the marketplace but if no risks are taken, there is never a new product produced and launched (Frishammar \& Horte, 2007). Frishammar and Horte (2007) postulate that risk taking influences new product development performance.

The final dimension of the entrepreneurial capability is proactiveness. Proactiveness is concerned with looking ahead and trying to be the first mover. Proactiveness refers to the ability of firms to seize the initiative in the persuit of marketplace opportunities and the ability of firms to act in anticipation of future changes to the market (Baker \& Sinkula, 2009). Lyon, Dess and Lumpkin, (2000) state that the goal is to gain an edge to shape the environment by introducing new products in the competition that will come (as cited in Frishammar \& Horte, 2007). According to Lumpkin and Dess (1996), proactiveness implies an attitude to look forward, along with the innovative activity or speculation. Furthermore, proactive firms are the ones that often propose a new product, and often introduce new products first or precede its competitors (Dess \& Lumpkin, 2005). In this case, the firms' competitive advantage depends on their speed to enter the market and their ability to meet customer needs (Li et al., 2008). Therefore, proactiveness should have a positive impact on the performance of the firm's new product development. The reason is, firstly, proactiveness has an advantage as a first mover (Frishammar \& Horte, 2007) which allows high profit on new products in the absence of competing product. Secondly, proactiveness implies an increase in the speed of new product development. Such a speed is an essential condition for the development of new products. Lastly, passivity is a firm's inability to seize the opportunity. This is really undesirable if the high performance of the new product development will be the firm's goals. Therefore the hypotheses as follows:

$\mathrm{H}_{1 \mathrm{a}}$ : Innovativeness has a positive influence on new product development performance.

$\mathrm{H}_{1 b}$ : Risk taking has a positive influence on new product development performance.

$\mathrm{H}_{1 c}$ : Proactiveness has a positive influence on new product development performance.

\subsection{Financial Literacy and New Product Development Performance}

Review of the literature indicates that most consumers lack of the financial literacy necessary to make important financial decisions in their own best interest (Perry, 2008; Oseifuah, 2010). The experts also agree that financial literacy appears 
directly related to self-beneficial financial behavior (Hilgert et al., 2003). Financial literacy is defined as the ability to make informed judgements and to take effective actions regarding the current and future uses and management of money (Basu, 2005).

Financial literacy includes an increase in financial knowledge and skills, and changes in financial behavior (Hilgert et al., 2003; Mandell, 2008; Oseifuah, 2010). In this case, the financial literacy has two dimensions, that is knowledge and action (Media Research Consultants Pte Ltd., 2005). Knowledge includes understanding of finance alternative. Meanwhile, actions include financial literacy about money, financial competence, and financial responsibility. In this case, it is clear that the interests of financial literacy can not be ignored, as someone with financial illiteracy may not be able to budget appropriately to meet its spending, and can not identify financial products or services that meet their needs, and the latter being a victim of fraud and exploitation practices (ASIC, 2003). Therefore, owners who are not skilled and also less knowledgeable in financial matters may tend to have a negative impact on their performance.

Meanwhile, previous studies concluded that an adequate financial literacy had a positive impact on company performance. Owners who have a good financial literacy will be able to accumulate and manage their wealth efficiently. Moreover, they can take effective decision with regard to their money management, financial planning, investment, retirement, asset, and finance alternative. The explanation above leads to the hypothesis as follow:

$\mathrm{H}_{2}$ : Financial literacy has a positive influence on new product development performance.

\subsection{The Moderating Role of Financial Literacy}

Research on the role of financial literacy as a moderating variable in the relationship between entrepreneurial capabilities and business performance, particularly the performance of new product development, is still rarely investigated. However, Oseifuah's (2010) study found that financial literacy among entrepreneurs was above average and contributed meaningfully to entrepreneurial skill. Thus, in this context, financial literacy may moderate the relationship between entrepreneurial capabilities and new product development performance.

The rationale underlies this argument is that if the entrepreneurs has a higher level of financial literacy, then they may have high productivity and profitability. Lastly, if the entrepreneurs have the lower level of financial literacy, it will result in the lower level of their work productivity (Fletcher et al., 1997, Joo \& Grable, 2000), decreased savings (Hilgert, 2003), accumulated consumer debt (Stango \& Zinman 2007) inadequacy of retirement planning (Lusardi \& Mitchell, 2007). Therefore, entrepreneur with sufficient financial literacy to encourage him to make decisions rationally and carefully. In this case the financial literacy plays an important role to moderate the relationship between entrepreneurial capability and performance of the firm's new product development. This explanation leads to the following hypotheses:

$\mathrm{H}_{3 a}$ : Financial literacy moderates relationship between innovativeness and new product development performance.

$\mathrm{H}_{3 b}$ : Financial literacy moderates relationship between risk taking and new product development performance.

$\mathrm{H}_{3 b}$ : Financial literacy moderates relationship between proactiveness and new product development performance.

\section{Method}

\subsection{Data and Sample}

The samples consist of micro-and small-sized enterprises, especially micro and small craft industry are located in the province of Yogyakarta, Indonesia. The samples use purposive sampling technique. The sample is determined based on several criteria. First, the micro- and small-sized craft industry that include leather products, silver, ceramics, pottery, rattan and furniture. Secondly, micro- and small- sized craft industry based on the definition of BPS: micro enterprises with number of workers less than 5 people and small enterprises with the number of workers 5-15 people.

The profile of the respondents is shown in table 1 . There are 133 respondents used in this study. In this study, interestingly, the majority of respondents were female (60.9\%). This figure shows that the female is more interested in this craft industry sector. The biggest age group are in the age range 30-50, (72.2\%). In this case, these figures show that young entrepreneurs still lack of interest in this craft industry. The majority of respondents were married (87.2\%). Most respondents had a high school degree (57.9\%). This phenomenon indicates the low level of the quality of human capital in the craft industry of micro and small enterprises, located in Yogyakarta, Indonesia. Meanwhile, in running their businesses, respondents are more oriented to the domestic market (97.7\%) than the foreign market. 
Table 1. Characteristics of Respondents

\begin{tabular}{|c|c|c|c|c|}
\hline \multicolumn{2}{|c|}{ Characteristic } & Aspect & Frequency & Percentage \\
\hline \multirow[t]{2}{*}{1} & \multirow[t]{2}{*}{ Gender } & Male & 52 & 39.1 \\
\hline & & Female & 81 & 60.9 \\
\hline \multirow[t]{4}{*}{2} & \multirow[t]{4}{*}{ Age } & $<30$ & 25 & 18.8 \\
\hline & & $30-40$ & 48 & 36.1 \\
\hline & & $>40-50$ & 48 & 36.1 \\
\hline & & $>50$ & 12 & 9.0 \\
\hline \multirow{2}{*}{3} & \multirow{2}{*}{ Marital Status } & Married & 116 & 87.2 \\
\hline & & Unmarried & 17 & 12.8 \\
\hline \multirow[t]{6}{*}{4} & \multirow[t]{6}{*}{ Education } & Illiterate & 3 & 2.3 \\
\hline & & Elementary School & 3 & 2.3 \\
\hline & & Secondary School & 7 & 5.3 \\
\hline & & Higher School & 77 & 57.9 \\
\hline & & Diploma & 15 & 11.3 \\
\hline & & Bachelor/Degree & 28 & 21.1 \\
\hline \multirow[t]{2}{*}{5} & \multirow[t]{2}{*}{ Market Target } & Domestic Market & 130 & 97.7 \\
\hline & & Overseas Market & 3 & 2.3 \\
\hline
\end{tabular}

\subsection{Measurement}

The variables of this study consist of dependent and independent variables, and moderating variable. The dependent variable is the performance on new product development. The independent variables is the entrepreneurial capability while the moderating variable is financial literacy. According to US Financial Literacy and Education Commission as cited by Basu (2005), financial literacy is the ability to make an informed judgment and effective decisions regarding the current and future use management of money (Oseifuah, 2010). As Cole and Fernando (2008) state that there is no standard measure of financial literacy (as cited in Oseifuah, 2010). The theoretical framework for measuring the financial literacy, as moderator variable was adapted from instruments developed by Oseifuah (2010). In this study, questionnaires are developed to capture information on the main aspects of financial literacy that include financial skill or financial behavior. Financial literacy is measured by ten items. These items include financial knowledge and skills, namely budgeting and tracking the expenditures, increased financial knowledge, financial management, financial planning, savings, financial reporting. Items of financial literacy were assessed using a five-point likert scale, $(1=$ strongly disagree, and $5=$ strongly agree).

Meanwhile, entrepreneurial capabilities reflect the extent to which firms tend to innovate, take risks, and act proactively (Frishammar and Horte, 2007). This study uses the instruments developed by Covin and Slevin (1999), and Frishammar and Horte (2007). First, innovativeness consists of three items. These items include an emphasis on innovation, namely excellence in technology, research and development of new products; new products offered during the last five years; dramatic changes in product. Second, risk-taking is composed of three items. These items include the tendency to high-risk and high profit projects, attitude towards risk, risk action. Third, proactiveness consists of three items. The items include an action precedes a competitor, being the first to launch a product, trying to deal with competitors. Items of the three dimensions of the entrepreneurial capabilities were assessed using a five-poin likert scale ( 1 , strongly disagree $=$ show entrepreneurial capability is very low, while 5 , strongly agree $=$ show very high entrepreneurial capability).

Finally, the performance of new product development is related to the extent to which a new product perceived will meet a market share, sales targets, and appropriate use of the customer, sales growth, and profit target. The performance of new product development at the company level is measured using an instrument used by Atuahene-Gima and Ko (2001) and Frishammar and Horte (2007). Performance on the development of new products consists of 4 items. Items include market share, sales growth, corporate profits, and return on assets. Items of new product development performance were assessed using a five-poin likert scale ( 1 = Strongly disagree and 5 = Strongly Agree).

\section{Results}

This study includes the main variables, namely entrepreneurship capability, financial literacy, interaction between entrepreneurial capabilities and financial literacy, and new product development performance. Table 2 shows descriptive 
data and the results of reliability and validity test. Test of reliability and validity of the instrument has been conducted.

The reliability of a measure is an indication of the stability and consistency which the instrument measures the concept. To assess reliability, Cronbach's alpha statistical test was used. A instrument is said to be reliable if it gives Cronbach alpha values $>0.70$ (Nunnally, 1981). The values of cronbach alpha for each factor are shown in the Table 2. Therefore, alpha reliability values are greater than the minimum standard $(\alpha>0.70)$ for all the factors. It can be concluded that the instruments of entrepreneurship capability, financial literacy, and new product development performance are reliable.

Table 2. Descriptive Data of Main Variable

\begin{tabular}{lcccccc}
\hline Variable & Mean & Std & Min & Max & Cronbach's Alpha Corrected Item-Total Correlation \\
\hline Entrepreneurial Capability & & & & & & \\
Inovativeness & 4.687 & 1.087 & 2.00 & 7.00 & 0.72 & $>0.30$ \\
Risk Taking & 4.491 & 1.257 & 1.33 & 7.00 & 0.74 & $>0.30$ \\
Proactiveness & 4.303 & 1.145 & 1.00 & 7.00 & 0.71 & $>0.30$ \\
Financial Literacy (FL) & 3.514 & 0.547 & 2.10 & 4.80 & 0.77 & $>0.30$ \\
Innovativeness*FL & 16.626 & 5.368 & 6.40 & 33.60 & - & \\
Risk Taking*FL & 16.04 & 5.879 & 3.86 & 33.60 & - & \\
Proactiveness*FL & 15.39 & 5.518 & 3.90 & 33.60 & - & $>0.30$ \\
New Product Development Performance & 3.618 & 0.624 & 1.25 & 5.00 & 0.73 & \\
\hline
\end{tabular}

Meanwhile, validity test is used to measure whether or not an instrument is valid. The instrument is valid if it can accurately measure what is to be measured. In other words, validity is concerned with the accuracy of the instrument. Analysis of the validity of the instrument is based on the correlation between the scores of each item with the total score. As for the validity of the critical value is 0.30 (Mueller, 1986:54). The magnitude of the correlation value of each item to the total score is shown on Table 2. The result of validity test shows that all items for each variable is above a critical value, $r>0.30$. Because each item has a correlation value that is greater than the minimum standards $(r>0.30)$, it can be concluded that all the items on the instrument is valid. Thus, financial literacy, entrepreneurial capabilities, and new product development performance, all the indicators are valid.

Futhermore, testing the hypotheses in this study is conducted with moderated regression analysis technique. Table 3 shows summary of moderated regression results. Model 1 reveals that innovativeness has no influence on new product development performance. Meanwhile, entrepreneurial capabilities on the other dimensions have a positive influence on new product development performance.

Table 3. Summary of Empirical Models

\begin{tabular}{|c|c|c|c|c|c|c|c|}
\hline Hypo-thesis & Variable & Model 1 & Model 2 & Model 3 & 3 Model 4 & Model 5 & Model 6 \\
\hline $\mathrm{H}_{1 \mathrm{a}}$ & Innovativeness & $\begin{array}{l}-0.02 \\
(-.34) \\
\end{array}$ & $\begin{array}{c}-0.05 \\
(-0.01) \\
\end{array}$ & $\begin{array}{c}-0.28 \\
(1.10) \\
\end{array}$ & $\begin{array}{l}-0.01 \\
(-.01) \\
\end{array}$ & $\begin{array}{c}0.03 \\
(0.45) \\
\end{array}$ & $\begin{array}{c}-0.25 \\
(-0.79) \\
\end{array}$ \\
\hline $\mathrm{H}_{1 \mathrm{~b}}$ & Risk Taking & $\begin{array}{c}0.12 \\
(2.42)^{*}\end{array}$ & $\begin{array}{c}0.06 \\
(1.43) \\
\end{array}$ & $\begin{array}{c}0.04 \\
(1.31) \\
\end{array}$ & $\begin{array}{c}0.55 \\
(2.55)^{\star}\end{array}$ & $\begin{array}{c}0.07 \\
(1.64) \\
\end{array}$ & $\begin{array}{c}0.47 \\
(1.80)^{\star *}\end{array}$ \\
\hline $\mathrm{H}_{1 \mathrm{a}}$ & Proactiveness & $\begin{array}{c}0.12 \\
(2.03)^{\star}\end{array}$ & $\begin{array}{c}0.03 \\
(0.54)\end{array}$ & $\begin{array}{c}0.03 \\
(0.57)\end{array}$ & $\begin{array}{c}0.04 \\
(0.74)\end{array}$ & $\begin{array}{c}0.57 \\
(2.48)^{*}\end{array}$ & $\begin{array}{c}0.51 \\
(1.84)^{\star *}\end{array}$ \\
\hline $\mathrm{H}_{2}$ & Financial Literacy & - & $\begin{array}{c}0.52 \\
(5.43)^{\star}\end{array}$ & $\begin{array}{c}0.92 \\
(2.56)^{*}\end{array}$ & $\begin{array}{c}1.14 \\
(4.00)^{*}\end{array}$ & $\begin{array}{c}1.18 \\
(4.13)^{\star}\end{array}$ & $\begin{array}{c}1.23 \\
(3.30)^{*}\end{array}$ \\
\hline $\mathrm{H}_{3 \mathrm{a}}$ & Inovativeness x Financial Literacy & - & - & $\begin{array}{c}-0.08 \\
(-1.13) \\
\end{array}$ & - & - & $\begin{array}{c}0.08 \\
(0.86)\end{array}$ \\
\hline $\mathrm{H}_{3 b}$ & Risk Taking x Financial Literacy & & & & $\begin{array}{c}-0.14 \\
(-2.30)^{*}\end{array}$ & - & $\begin{array}{c}-0.14 \\
(-1.54)\end{array}$ \\
\hline $\mathrm{H}_{3 \mathrm{c}}$ & Proactiveness x Financial Literacy & & & & & $\begin{array}{c}-0.16 \\
(-2.43)^{\star}\end{array}$ & $\begin{array}{c}-0.12 \\
(-1.73)^{\star *}\end{array}$ \\
\hline & Adjusted $\mathrm{R}^{2}$ & 0.117 & 0.28 & 0.28 & 0.30 & 0.30 & 0.31 \\
\hline & F-test & $6.86^{*}$ & $13.64^{*}$ & $11.20 *$ & $12.35^{\star}$ & $12.51^{*}$ & $9.32^{*}$ \\
\hline
\end{tabular}

Note: *signifikan at critical value, $a=5 \%$

${ }^{* *}$ signifikan at critical value, $a=10 \%$ 
According to table 1, results of model 1 indicates that risk taking has positive effect on performance of new product development ( $p$-value $=0.5<a=0.05)$. Likewise, proactive has significant positive influence on performance of new product development ( $p$-value $=0.017<a=0.05$ ).

Model 2 includes entrepreneurial capabilities (innovativeness, proactive, and risk taking) and financial literacy. The fourth variable serves as the independent variable. In this model, the results show that entrepreneurial capabilities (innovativeness, proactive, and risk taking) have no significant effect on performance of new product development. These results are contrary to the model 1 . As expected, financial literacy has impact ( $p$-value $=0.00<a=0.05$ ). Meanwhile, these results reveal that financial literacy affects the performance of new product development.

Furthermore, model 3 is added to model 1 financial literacy, as moderating variable. Results show that financial literacy has effect ( $p$-value $=0.012<\alpha=0.05$ ) on new product development performance, but instead entrepreneurial capabilities show no such effect. This result is consistent with model 2 , that financial literacy has a positive influence on the performance of new product development. Contrary to prediction, financial literacy does not moderate the relationship between innovativeness and financial literacy. This result shows there is no interaction effect of the innovativeness and financial literacy, $(p$-value $=0.259>a=0.10)$ on the performance of new product development.

Model 4 shows that risk taking has significant positive effect ( $p$-value $=0.012<a=0.05$ ) on new product development performance, whereas the other two variables, namely innovativeness and proactiveness are not significant. Meanwhile, as expected financial literacy has significant positive ( $p$-value $=0.00<a=0.01$ ) effect. These results are consistent with model 2 and 3 , that financial literacy has a positive influence on the performance of new product development. Likewise, result shows that financial literacy moderates the relationship between risk taking and financial literacy. This result reveals there is a significantly negative interaction effect of the risk taking and financial literacy, ( $p$ value $=0.023<a=0.10$ ) on the performance of new product development.

Model 5 shows that proactiveness has a significant positive effect ( $p$-value $=0.014<a=0.05$ ), whereas the other two variables, namely innovativeness and risk-taking has no such effect. Meanwhile, financial literacy has a positive influence $(p$-value $=0.00<\alpha=0.01)$ on new product development performance. These results are consistent with models 2 and 3, that financial literacy has a positive influence on new product development performance. Likewise, financial literacy moderates between proactiveness and financial literacy ( $p$-value $=0.017<a=0.10$ ). This result reveals there is a significant negative interaction effect of the proactiveness and financial literacy on the performance of new product development.

Model 6 reveals that risk taking has effect ( $p$-value $=0.074<a=0.10$ ) on new product development performance. Moreover, proactiveness has a significant positive effect, ( $p$-value $=0.069<\alpha=0.10)$ on new product development performance, whereas other variable, namely innovativeness is not significant. Meanwhile, financial literacy has significant effect, ( $p$-value $=0.001<a=0.01$ ). This result is consistent with model $1,2,3$ and 4 , that financial literacy has a positive influence on the performance of new product development. Likewise, financial literacy moderates between proactiveness and new product development performance. This result shows there is a significant negative interaction effect of the proactiveness and financial literacy, ( $p$-value $=0.087<a=0.10)$ on the new product development performance. Meanwhile two other interactions have no effect on new product development performance.

In summary, the results of moderated regression analysis on all models show that risk taking and proactiveness have an influence on new product development performance. These results support hypotheses $\mathrm{H}_{1 \mathrm{~b}}$ and $\mathrm{H}_{1 \mathrm{c}}$. Meanwhile, innovativeness has no effect on the performance of new product development. This result does not support hypothesis $\mathrm{H}_{1 \mathrm{a}}$. Moreover, in all models, financial literacy has a positive effect consistently on new product development performance. These results support the second hypothesis $\left(\mathrm{H}_{2}\right)$. Furthermore, the results show that there is the negative interaction effect of risk taking and financial literacy on new product development performance. Likewise, the results show there is a negative interaction effect of proactiveness and financial literacy. These results reveal that the financial literacy variables serve as a moderating variable on the relationship between proactiveness and new product development performance. These results support the third hypotheses $\left(\mathrm{H}_{3 a}, \mathrm{H}_{3 b}\right)$. However, financial literacy does not have a moderating role in the relationship between innovativeness and performance of new product development.

\section{Discussion}

Based on the empirical model (model 4, 5, and 6), the research reveals that financial literacy serves as a moderating variable in the relationship between risk taking and new product development performance. Likewise, the results of this study reveals that financial literacy moderates on relationship between risk taking and new product development performance. These results are consistent with the result of Oseifuah's (2010) study which shows that the financial literacy among entrepreneurs appears to be above average. In this case, the level of financial literacy contributes 
substantially to entrepreneurship skills. Entrepreneurial capabilities and good financial literacy is expected to have implications on the business performance and increase the growth of micro and small businesses. In this study it is clear that financial literacy serves as a moderating variable in the relationship between entrepreneurial capabilities (proactiveness and risk taking) and the performance of new product development.

The result of this study reveals that there is a significantly negative interaction effect of the risk taking and financial literacy on the performance of new product development. The result also reveals that high financial literacy weakens the positive effect of risk taking on new product development performance. These results are in line with Beal and Delpachitra's (2003) study, which shows that students with a high level of financial literacy are more likely to have lower aggregate risk preferences. Smaller firms might choose project or initiatives with a lower degree of risk, due to limitation in size and resource commitment. Likewise, result shows that there is a significantly negative interaction effect of the proactiveness and financial literacy on the new product development performance. The result indicates that high financial literacy level weakens the positive effect of proactiveness on new product development performance. In this case, first mover advantage-generating efforts are also likely to involve high degree of enterprise risk, such as operational and market risk. Thus, smaller firm may not possess adequate capabilities and resources to exploit the new opportunities a head of competition.

In addition, this study also shows that financial literacy affects the performance of new product development. These results are in line with the expectation that financial literacy has a positive impact on the performance of new product development. Entrepreneurs who have entrepreneurial skills with high performance require them to have a good financial literacy. Entrepreneurial capabilities do not always affect the performance of new product development. Therefore, it is important to consider the role of financial literacy as moderating variable. This view is in line with Taylor and Wagland, (2011) who state that financial security could only be achieved if people financially literate. Moreover, this result is consistent with Oseifuah's (2010) research which indicates that financial literacy contributes significantly towards entrepreneurial skills. In this regard, an entrepreneur needs to be financially literate if he makes informed decisions about debt, savings, and investment. The entrepreneur must be able to take effective decisions in managing their finanace. Therefore, entrepreneurs with sufficient financial literacy to encourage them to make decisions rationally and carefully.

Futhermore, the results of the study reveal that the risk taking and proactiveness affect the performance of new product development. These results are also consistent with previous studies which proves that the entrepreneurial capability affects the performance of new product development (Frishammar \& Horte, 2007). However, innovativeness does not affect the performance of new product development. This may occur because the micro and small enterprises do not have sufficient resources and capabilities in their efforts of innovativeness.

\section{Conclusion, Implications, Limitations and Future Research}

Results of this study concludes several important things. First, financial literacy has a role in moderating the relationship between risk taking and new product development performance. Likewise, financial literacy has a moderating role in the relationship between proactiveness and new product development performance. Second, the results show that financial literacy has positive influence on the performance of new product development. Third, the results show that the dimensions of entrepreneurial capability: risk taking and proactiveness have a positive effect on the performance of new product development.

This study has several implications for the management of micro and small enterprises. First, the entrepreneurs of micro and small businesses that are interested in improving the performance of new product development should encourage them to have a better financial literacy. Financial literacy includes at least skills in budgeting and expenditure tracking, improved financial knowledge, financial management, financial planning, savings, financial reporting. Mastery of financial literacy throughout the new product development process will lead to higher product success.

This study reveals some questions that were beyond the scope of this study, but an opportunity for future research. Firstly, although the role of financial literacy as a moderating variable between entrepreneurial capability and performance of new product develops, but this study has not been consideration of other independent variables such as marketing capabilities, technology capabilities. Likewise, research has not yet to take into account other moderator variables, such as the level of competition, the degree of novelty products for customers and other business environment factors. Second, this study also does not take into account the role of mediating variables, such as innovativeness success. Future research may also consider the success of innovativeness as a mediating variable. Inovativeness success may mediate between the entrepreneurial capability and profitability of the company. Third, in the micro and small enterprises, the results show that innovativeness has no effect on the performance of the company's new product development. These results indicate the micro and small companies do not yet have sufficient innovation capabilities due 
to limited financial resources to bear the new product fails. Therefore, the mediating role of innovativeness on the performance of new product development and profitabiliats, should also be investigated in medium and large companies.

\section{References}

ASIC (2003). Financial Literacy in Schools: ASIC Discussion paper. Australian Securities and Investments Commission, Melbourne, available at www.fido.asic.gov.au/fido/ fido.nsf /byheadline/financial+literacy/opendocument.

Atuahene-Gima, K \& Ko, A. (2001). An empirical investigation of the effect of market orientation and entrepreneurship orientation alignment on product innovation. Organization Science, 12(1), 54-74.

Baker, W.E and Sinkula, J.M (2009). The Complementary Effects of Market Orientation and Entrepreneurial Orientation on Profitability in Small Business, 47(4):443-464.

Basu, S. (2005). Financial Literacy and the Life Cycle. Financial Planning Association, Washington, DC.

Beal, D.J. and Welch, C. (2002). Financial Literacy among Australian Student. Economic Papers, 22(1):65-78.

Bosma, N. \& Harding, R. (2006). Global Entrepreneurship Minitor (GEM) 2006 Report. London. Babson College and London Business School.

Cole, S. \& Fernando, N. (2008). Assesing the Importance of Financial Literacy. Asian Development Bank Quarterly News Letter: Finance for the Poor, 9(3):1-81-8

Covin, J. G. \& Slevin, D. P. (1999). Strategic management of smaller firms in hostile and benign environments. Strategic Management Journal, 10(1), 75-87

Davis, J.L., Bell, R.G., Payne, G.T., \& Kreiser, P.M. (2010). Entrepreneurial Orientation and Firm Performance: The Moderating Role of Managerial Power. American Journal of Business, 25 (2), 42-54.

Dess, G. G. \& Lumpkin, G. T. (2005). The role of entrepreneurial orientation in stimulating effective corporate entrepreneurship. Academy of Management Executive, 19(1), 147-156;

Fletcher, CN., Beebout, G. \& Mendenhall, S. (1997). Developing and Evaluating Personal Finance Education at The Worksite: Case Study. Personel Finance and Worker Productivity. 1(1), 54-59

Frank, H., Kessler, A. \& Fink, M. (2010). Entrepreneurial Orientation and Business Performance: A Replication Study. SBR, 62, 175 198.

Frishammar, J. \& Hörte, S.Å. (2007). The Role of Market Orientation and Entrepreneurial Orientation for New Product Development Performance in Manufacturing Firms. Technology Analysis \& Strategic Management, 22(3), 251-266.

Hilgert, M.A. Hogarth, J.M. \& Beverly, S.G. (2003). Household Financial Management: the Connection Between Knowledge And Behaviour. NBER Working Paper 14538

Joo, S. \& Grable, J.E. (2000). Improving Employee Productivity: The Role of Financial Counselling and Education. Journal of Employment Counselling, 37, 2-15

Kreiser, P. M., Marion, L. D. \& Weaver, K. M. (2002). Assessing the Psychometric Properties of the Entrepreneurial Orientation Scale: A Multi-Country Analysis. Entrepreneurship Theory \& Practice, 26(4), 49-66.

Li, Y., Zhoa, Y., Tan, J. \& Liu, Y. (2008). Moderating Effects of Entrepreneurial Orientation on Market Orientation-Performance Lingkage: Evidence From Chinese Small Firms. Journal of Small Business Management, 46(1): 113-134.

Lumpkin, G. T. and Dess, G. G. (1996). Clarifying The Entrepreneurial Orientation Construct and Linking It To Performance. Academy of Management Review, 21(1), 135-172.

Lusardi, A. \& Mitchell, O.S. (2007). Financial Literacy and Retirement Preparedness: Evidence and Implication for Financial Education. Business Economics. 42, 35-44.

Lyon, D.W., Dess, G.G, \& Lumpkin, D.G. (2000). Enchancing Entrepreneurial Orientation Research: Operationalizing and Measuring a Key Strategic Decision Making Process. Journal of Management, 26(5): 1055-1085.

Mandell, L. (2004). Financial Literacy: Are We Improving? Jumpstart Coalition for Personal Financial Literacy, Washington DC

Media Research Consultants Pte Ltd. (2005). Quantitative Research On Financial Literacy Levels in Singapore, report prepared for The Money Financial Education Steering Committee (FESC), Singapore.

Mueller, D.J. (1986). Measuring social attitudes: A Handbooks for Researchers and Practitioners. New York: Teachers College Press, Columbia University.

Nunally, J.C. (1980). Psychometric Theory, Second Edition. New Yorks: MacGraw-Hill.

Oseifuah, E, K. (2010). Financial Literacy and Youth Entrepreneurship in South Africa. African Journal of Economic and Management Studies, 1 (2), 164-182

Perry, V.G. (2008). Is ignorance bliss? Consumer Accuracy in Judgments about Credit Ratings. Journal of Consumer Affairs, 42 (2), 189 $-205$.

Stango, V. \& Zinman, J. (2007). The Price isnot Right (not even on average): Exponential Growth Bias. Present biased Perception and Household Finance. Working Paper. Darthmauth College, Hanover.

$\mathrm{Su}, \mathrm{X} .$, Xie, E. \& Li, L. (2011). Entrepreneurial Orientation and Firm Performance in New Ventures and Established Firms. Journal of Small Business Management, 49(4), 558-577. 